\section{Initial Survival of Pecan Grafts on Seedling Rootstock of Pecan, Water Hickory, and their Interspecific Hybrid}

\author{
L.J. Grauke' and \\ Richard D. O'Barr'
}

Additionsal index words. Carya illinoinensis, Carya aquatica, Carya $\times$ lecontei, site selection, iron uptake

Summary. 'Oconee' pecan [Carya illinoinensis (Wangenh.) K. Koch] scions were grafted on seedling rootstock from nine open-pollinated seedstocks. Rootstock included three seedstocks each of pecan, water hickory $[C$. aquatica (F. Michx.) Nutt.], and their interspecific hybrid, Carya $\times$ lecontei (Little). Pecan seedlings had the largest basal diameters and water hickory seedlings the smallest. Seedlings of 'Elliott' and 'Curtis' seedstocks were larger than seedlings from 'Moore' seedstock. Pecan and $C . \times$ leconte $i$ seedlings were grafted more successfully than water hickory. Graft success varied among seedstocks of pecan and $C . \times$ lecontei Foliage color of seedlings, possibly indicative of iron nutritional status, was influenced by species; pecan seedling leaves were darker green than those of water hickory seedlings, but similar to $C$. $\times$ lecontei leaves. 'Oconee' scion leaves were darker green on pecan rootstock than when grafted on C. $\times$ lecontei rootstock.

Research conducted at LSU Pecan Research Extension Station, Shreveport, La.

'Reseavch Horticulturist, USDA, ARS Pecan Breeding and Genetics, Route 2, Box 133, Somerville, TX 77879.

${ }^{2}$ Professor, LSU Pecan Research Extension Station, P.O. Box 5519, Shreveport, LA 71135. The cost of publishing this paper was defrayed in part by the payment of page charges. Under postal regulations, this paper therefore must be hereby marked advertisement solely to indicate this fact.
$\mathrm{I}$ n many sites in Louisiana, Mississippi, and Texas, growth of pecan (Carya illinoinensis) trees is limited by poorly drained, water-saturated soils. Many such sites support the growth of water hickory (C. aquatica). Water hickory has been used as a rootstock for pecan scions with limited success (Sitton and Dodge, 1938; Reed, 1944). Pecan scions on water hickory rootstock exhibit reduced growth, often have chlorotic foliage, and yield less than pecan scions on pecan rootstock (Sitton and Dodge, 1938).

Pecan and water hickory interbreed to form the interspecific hybrid C. $\times$ lecontei (Little), commonly called bitter pecan. In natural stands, $C$. xlecontei usually occupies sites intermediate to the well-drained sites required by pecan and the saturated sites tolerated by water hickory. Toliver and Stauder ( 1982 ) compared growth of pecan, water hickory, and C. $\times$ lecontei on a poorly drained silt loam soil in East Feliciana Parish, La. They found water hickory to be the largest, pecan the smallest, and $C . \times$ lecontei intermediate at 3 years of age. Pollen parent influenced the vigor of C. $\times$ leconte $i$ seedlings; seedlings of $C . \times$ leconte $i$ backcrossed to pecan were more vigorous than seedlings of $C . \times$ lecontei pollinated by other $C$. $\times$ lecontei seedlings, but less vigorous than $C . \times$ lecontei backcrossed to water hickory.

Carya $\times$ lecontei seedlings may have potential as rootstock for pecan, especially on poorly drained soils under irrigation. Critical parameters to consider in making that assessment are vigor of seedlings relative to pecan and graft survival compared to survival on pecan rootstock. To evaluate those parameters, a nursery was established with pecan, water hickory, and $C$. $\times$ lecontei seedlings. This report documents seedling size and initial graft survival as influenced by species and seedstock in that nursery.

The term hybrid can be confusing in horticultural usage. From a botanical standpoint, a hybrid is the result of crossing two species. Recognition of the hybrid rests on familiarity with characteristics of the parent species, which are blended in the phenotype of the their interspecific cross. Since the generation of the cross is usually unknown in natural populations, no implication of generation is implied by use of the term hybrid by botanists. 
Table 1. Seedling diameter and 'Oconee' graft success in nine rootstocks of pecan.

\begin{tabular}{lccr}
\hline Variable & No. of observations & Basal diam (mm) & Graft success (\%) \\
\hline Species & & & \\
Pecan & 154 & $27.7 \mathrm{a}^{2}$ & $34.9 \mathrm{a}$ \\
Carya $\times$ lecontei & 89 & $25.0 \mathrm{~b}$ & $39.5 \mathrm{a}$ \\
Hickory & 90 & $22.7 \mathrm{c}$ & $7.1 \mathrm{~b}$ \\
Seedstock within sp. & & & \\
Pecan & 40 & $30.4 \mathrm{a}$ & $42.9 \mathrm{a}$ \\
Elliott & 63 & $27.9 \mathrm{a}$ & $30.1 \mathrm{a}$ \\
Curtis & 51 & $24.8 \mathrm{~b}$ & $31.7 \mathrm{a}$ \\
Moore & 33 & $26.5 \mathrm{a}$ & $16.1 \mathrm{~b}$ \\
Carya $\times$ lecontei & 27 & $24.0 \mathrm{a}$ & $51.0 \mathrm{a}$ \\
Pratt & 29 & $24.4 \mathrm{a}$ & $51.3 \mathrm{a}$ \\
Robson & & & \\
Montgomery & 38 & $24.3 \mathrm{a}$ & $6.0 \mathrm{a}$ \\
Hickory & 36 & $23.8 \mathrm{ab}$ & $12.9 \mathrm{a}$ \\
Aq-1 & 16 & $19.9 \mathrm{~b}$ & $2.2 \mathrm{a}$ \\
Aq-3 & & & \\
Aq-2 & & & \\
\hline s.teast-squaresmianseparation for & & & \\
\hline
\end{tabular}

Interspecific hybrids are given specific epithets according to the same rules that govern naming of species, the International Code of Botanical Nomenclature (ICBN). Their names are distinguished by preceding the species name with " $x$ ". Geneticists often use the term hybrid for various levels of controlled pollinations. In the walnut industry, 'Paradox' hybrid rootstock are the $F_{1}$ generation of seedlings resulting from pollination of Juglans hindsii (Jeps.) Rehder with pollen from J. regia L. (McGranahan and Leslie, 1991). In the pecan industry, controlled cross matings between pecan parents are said to produce hybrid seed. Botanical nomenclature is used in this paper to reduce confusion associated with the term hybrid.

\section{Materials and methods}

Three seedstocks each of pecan, water hickory, and C. ×lecontei were collected in October 1986. Seeds of 'Curtis', 'Elliott', and 'Moore' pecan were collected at the LSU Pecan Research Extension Station, Shreveport. Water hickory seeds were collected in Caddo and Bossier Parish, La., from native trees designated as Aq-1, Aq-2, and Aq-3. Carya $\times$ lecontei seeds were collected from trees adjacent to pecan orchards in Caddo, DeSoto, and Bossier Parish, and were designated as 'Robson', 'Pratt', and 'Montgomery,' respectively. Voucher specimens of seed source trees are maintained at the USDA, ARS Pecan Breeding and Genetics Station, Somerville, Tex.
Although pollination was not controlled, the location of source trees suggests that all pecan and $C$. x leconte $i$ seedstocks were pollinated by pecan. linated by adjacent water hickories. However, Aq-2 and Aq-3 could have been pollinated by water hickory, pecan, or $C$. Xlecontei. Seed were stratified in moist sphagnum moss at $4 \mathrm{C}$ from November until planting, 28 Apr. 1987.

The nursery site was on a Moreland taxadjunct (fine, mixed, thermic Aquic Udifluvent) in Caddo Parish, La. The nursery was planted in a randomized complete-block design with nine blocks, each having nine rows. Each seedstock comprised one row (plot) in each block, with seed 40 $\mathrm{cm}$ apart in the row and rows $1.8 \mathrm{~m}$ apart. Eleven seeds of each seedstock were sown in each plot, except for 'Robson' $C$. x lecontei, of which only nine seeds were planted, with remaining positions sown with filler seed.

Seedlings were grafted with scions of 'Oconee' pecan on 20-21 June 1991, using a modified four-flap graft technique (Vanerwegen, 1975). Grafts were not wrapped with aluminium foil or plastic, based on previous observations under Louisiana conditions. Four individuals performed the grating, each propagator working consecutive rows through all blocks to ensure exposure to all rootstock. Graft survival was recorded 18 Sept. 1991, along with seedling basal diameter measured $5 \mathrm{~mm}$ from the ground. Seedlings Water hickory Aq-1 was probably pol- were assigned to diameter classes as follows: $1=0$ to $10 \mathrm{~mm} ; 2=11$ to 20 $\mathrm{mm} ; 3=21$ to $30 \mathrm{~mm} ; 4=31$ to 40 $\mathrm{mm} ; 5=$ over $40 \mathrm{~mm}$. Also on that date, each seedling was rated for foliage color, with dark green $=1$, medium green $=2$, or yellow green $=3$, corresponding in the Munsell system of color notation (Anonymous, 1977) to $7.5 \mathrm{GY} 3 / 2,5 \mathrm{GY} 5 / 4$, or $2.5 \mathrm{GY}$ $6 / 6$, respectively.

Data were analyzed using the SAS Institute general linear models procedure for unbalanced design. Leastsquares means were separated using paired $t$ tests.

\section{Results}

Graft survival was influenced by propagator (data not shown). Subsequent statistical analyses of graft success were classed and modeled by propagator to control that source of variation in the test. Investigation of failed grafts indicated the primary cause of failure to be excessive tightness in wrapping. Poor fit at the basal cut, accompanied by fungal growth, was observed on some failed grafts.

Grail success was influenced by species, with less take of scions on water hickory rootstock than on pecan or $C$. Xlecontei rootstock (Table $1)$.

Graft success was influenced by seedstock in C. Xlecontei rootstock, 'Montgomery' and 'Robson' rootstock having greater success than 'Pratt' (Table 1). No differences in graft success were apparent between seedstocks of pecan or water hickory.

Graft success was not influenced by diameter class, with only $33 \%$ of all grafts surviving.

Diameter of seedlings was influenced by species and seedstock in pecan and water hickory (Table 1). Pecan seedlings were larger than either $C$. $\times$ lecontei or water hickory seedlings, with $C$. $\times$ lecontei being larger than water hickory. Within pecan seedstocks, 'Elliott' and 'Curtis' seedlings were larger than 'Moore'. Among water hickory seedstocks, Aq-2 was smaller than Aq-1, but could not be distinguished from Aq-3.

Some seedlings developed interveinal chlorosis on new growth, which is a characteristic of iron deficiency. Composite soil samples were taken from each block, using soil from each of the nine plots. Soil $\mathrm{pH}$ ranged from 7.8 to 8.4 and was positively corre- 
lated with chlorosis of the foliage of rootstock $(\mathrm{Y}=0.884678 \mathrm{X}-5.10598$, $\left.R^{2}=0.7046\right)$. The color of 'Oconee' foliage was not significantly related to $\mathrm{pH}$, or any other soil parameter measured.

Pecan seedling rootstock were darker green than hickory rootstock, but were inseparable in color from hybrid rootstock (Table 2). For all seedstocks, foliage color of 'Oconee' was lighter green than that of rootstock foliage. 'Oconee' scions growing on pecan rootstock were darker green than those growing on $C$. $\times$ lecontei rootstock. Low numbers of observations for grafted water hickory reduced the power of the test and prevented mean separation, despite apparent differences.

Within species, seedstocks affected foliage color (Table 2). Ungrafied pecan seedlings were uniformly dark green and indistinguishable from each other. However, 'Oconee' scions on 'Elliott' were darker green than those grafted to 'Moore' seedling rootstocks. 'Robson' C. xlecontei seedling rootstock were darker green than those of other $C$. Xlecontei seedstocks. However, scions grafted on $C$. Xlecontei rootstock could not be distinguished on the basis of color. Seedlings of Aq1 were darker green than those of Aq3. Water hickory rootstock could not be separated from each other on the basis of 'Oconee' foliage color.

\section{Discussion}

Results of this study are superficially inconsistent with previous reports by Toliver and Stauder (1982), who reported greatest growth in water hickory seedlings and least in pecans, opposite to the pattern reported here. Their test was planted on Cacilla and Calhoun silt loam soils at the Idlewild Experiment Station, East Feliciana Parish, La. The site is frequently flooded, is poorly drained and very poorly aerated, and is unsuitable as a site for pecan, although it is typical of sites where water hickory is found. The Shreveport nursery is located on a Moreland silt loam, which is deep, well drained, and protected from flooding. The site is excellent for pecan. The disparity in performance of the species in the two tests may be due to differences in the test sites.

Grauke and Pratt ( 1985 ) reported 'Elliott' seedlings to be taller than those of 'Moore', but similar in height to 'Curtis'. In this study, 'Elliott' and 'Curtis' seedlings had larger trunk diameters than seedlings of 'Moore'. Recognition of consistent patterns of performance by open-pollinated seedstocks has been the foundation of improved seedstock selection (Grauke, 1991).

Under conditions of this study, water hickory rootstock had reduced graft success compared to pecan and

Table 2. Foliage color of rootstocks and 'Oconee' scions.

\begin{tabular}{|c|c|c|c|c|}
\hline \multirow[b]{2}{*}{ Variable } & \multicolumn{2}{|c|}{ Rootstock foliage } & \multicolumn{2}{|c|}{ Oconee foliage } \\
\hline & No. of observations & color $^{2}$ & No. of observations & color \\
\hline \multicolumn{5}{|l|}{ Species } \\
\hline Pecan & 94 & $1.74 b^{y}$ & 60 & $2.18 \mathrm{~b}$ \\
\hline Carya $\times$ lecontei & 49 & $1.91 \mathrm{~b}$ & 40 & $2.32 \mathrm{a}$ \\
\hline Hickory & 79 & $2.23 \mathrm{a}$ & 11 & $2.41 \mathrm{ab}$ \\
\hline \multicolumn{5}{|l|}{ Seedstock within sp. } \\
\hline \multicolumn{5}{|l|}{ Pecan } \\
\hline Elliott & 20 & $1.70 \mathrm{a}$ & 20 & $2.02 \mathrm{~b}$ \\
\hline Curtis & 43 & $1.72 \mathrm{a}$ & 20 & $2.22 \mathrm{ab}$ \\
\hline Moore & 31 & $1.80 \mathrm{a}$ & 20 & $2.29 \mathrm{a}$ \\
\hline \multicolumn{5}{|l|}{ Carya $\times$ lecontei } \\
\hline Robson & 11 & $1.26 \mathrm{~b}$ & 16 & $2.36 \mathrm{a}$ \\
\hline Pratt & 21 & $2.16 \mathrm{a}$ & 9 & $2.37 \mathrm{a}$ \\
\hline Montgomery & 14 & $2.32 \mathrm{a}$ & 15 & $2.21 \mathrm{a}$ \\
\hline \multicolumn{5}{|l|}{ Hickory } \\
\hline $\mathrm{Aq}-\mathrm{l}$ & 34 & $2.00 \mathrm{~b}$ & 4 & $\cdot 2.39 \mathrm{a}$ \\
\hline $\mathrm{Aq}-3$ & 29 & $2.34 \mathrm{a}$ & 7 & $2.42 \mathrm{a}$ \\
\hline $\mathrm{Aq}-2$ & 16 & $2.35 \mathrm{ab}$ & 0 & \\
\hline
\end{tabular}

${ }^{z}$ Color rated on scale of $1=$ dark green; $2=$ green; $3=$ yellow green.

${ }^{y}$ Least-squares mean separation for each level of species and seedstock within species by paired test, $\mathrm{P}<0.05$.

C. $\times$ lecontei rootstock. Carya $\times$ lecontei rootstock were comparable to pecan as rootstock for pecan scions. Whether the same pattern of graft success would obtain on sites adapted to water hickory is a question to be addressed in future research.

Foliage color of pecan seedlings was darker green than that of water hickory seedlings. Chlorosis of seedlings was possibly caused by iron deficiency. Sitton and Dodge (1938) reported increased iron deficiency symptoms on pecan scions grafted to water hickory rootstock. Carya $\times$ lecontei seedlings varied greatly in foliage color, as a function of seedstock, indicating the potential for selection of seedstocks comparable to pecan in foliage color.

Volubility of hydrous ferric oxide in soil is $\mathrm{pH}$-dependent, with increased volubility at decreased $\mathrm{pH}$. Water hickory grows on sites that are typically more acid than those preferred by pecan (Grauke et al., 1987). Welldrained soils maintain concentrations of iron well below the minimum needed for plant growth, necessitating plant adaptations for increased iron uptake (Olsen et al., 1981). Under anaerobic conditions, such as are common at water hickory sites, iron toxicity may occur due to high concentrations of divalent iron, the form absorbed by plant roots. Survival of water hickory in its native sites may depend on efficient exclusion of iron, while survival of pecan at its native sites may necessitate enhanced uptake of the element. Differences in the nutrient status of pecan scions on pecan and $C . \times$ leconte $i$ rootstock should be investigated further.

The potential for use of $C$. $\times$ lecontei rootstock for pecan scions is not limited by initial graft success. Possibly, seedstocks of the $C$. xlecontei could be selected on the basis of increased graft success. Future work should expand the scope of the present research, in numbers of seedstocks, scions, and sites evaluated. It remains to be determined if $\mathrm{C}$. $\times$ lecontei rootstock have any advantages compared to pecan rootstock, and under what conditions those advantages might be apparent.

\section{Literature Cited}

Anonymous. 1977. Munsell color charts for plant tissues. Munsell Color, Baltimore, Md. 
Grauke, L.J. 1991. The development of selection criteria for pecan seedstocks. In: B.W. Wood and J.A. Payne (eds.). 1st Natl. Pecan Workshop Pecan Husbandry: Challenges and Opportunities. U.S. Dept. Agr., Agr. Res. Serv.

Grauke, L.J. and J.W. Pratt. 1985. Pecan rootstock research. Proc. Southeast. Pecan Grow. Assn. 78:123-130.

Grauke, L.J., J.W. Pratt, and H. Morris. 1987. Phenology and site adaptations of Louisiana hickories. p. 181-185. In: Research report: Pecan Research-Extension Station. LSU Agr. Res. Center, Baton Rouge.

McGranahan, G. and C. Leslie. 1991. Walnuts (Juglans). p. 907-951. In: J.N. Moore and J.R. Ballington (eds.). Genetic resources of temperate fruit and nut Crops. Intl. Soc. Hort. Sci., Wageningen.

Olsen, R.A., R.B. Clarke, and J.H. Bennett. 1981. The enhancement of soil fertility by plant roots. Amer. Sci. 69:378-384.

Reed, C.A. 1944. Hickory species and stock studies at the Plant Industry Station, Beltsville, Mayland. Annu. Rpt. N. Nut Grower's Assn. 35:88-121.

Sitton, B.G. and F.N. Dodge. 1938. Growth and fruiting of three varieties of pecans on different seedling rootstock. Proc. Amer. Soc. Hort. Sci. 38:121-125.

Toliver, J.R. and A.F. Stauder, III. 1982. Variation among three-year-old seedlings of pecan, water hickory and their hybrids from controlled pollination experiments. Proc. N. Amer. For. Biol. Workshop 7:203206.

Vanerwegen, J. 1975. A new grating procedure for pecan stocks of small diameter. Pecan South 2(2):70-71. 